\title{
First record of Parastenocarididae (Crustacea, Copepoda, Harpacticoida) from subterranean freshwater of insular Greece and description of two new species.
}

\author{
Vezio Cottarelli and Maria Cristina Bruno *
}

\begin{abstract}
SUMMARY
The genus Parastenocaris, new for Greece, has been discovered in the hyporheic habitat of Kos and Kythira Island with two new species, that are described and discussed in this work. Parastenocaris aesculapii $\mathrm{n}$. sp. shares some characters with $P$. nolli from Germany and $P$. italica from Italy, Macedonia and Turkey. Parastenocaris aphroditis $\mathrm{n}$. sp belongs, according to the Authors, to a group of species living exclusively in estuarine interstitial habitats, which are all characterised by peculiar morphology and ecology, that are as well considered and interpreted.
\end{abstract}

\section{INTRODUCTION}

The large genus Parastenocaris Kessler, 1913, is almost exclusive of subterranean waters from all over the world; according to Dussart \& Defaye (1990), it is widely distributed in Southern Europe except, strange enough, in Greece. For this area there is only one dubious report on the presence of Parastenocaris (see above), even if subterranean habitats have been recently investigated (Bruno \& Cottarelli, in press; Forniz et al., 1990; Pesce, 1981, 1985; Pesce \& Maggi, 1983). This gap has now been filled with the record of two new species from the Greek Islands of Kos and Kythira, that are described and discussed here. Some remarks on relationship, biogeography and ecology of these Parastenocaris, will also be considered.

\section{MATERIAL AND METHODS}

Samples were collected using the Karaman-Chappuis method, fixed in $5 \%$ buffered Formalin. Specimens were mounted in permanent slides with Faure's medium and drawn at $1250 \mathrm{X}$, with an oil immersion lens, using a

* Dipartimento di Scienze Ambientali, Università della Tuscia. Via San Camillo de Lellis 01100 Viterbo, Italy. 
drawing tube mounted on a Zeiss Axioskop phase contrast microscope. The following abbreviations are used, when required, throughout the text and figures: $\mathrm{A} 1=$ antennula; $\mathrm{A} 2=$ antenna; $\mathrm{Bsp}=$ basipodite; $\mathrm{Enp}=$ endopodite; $\mathrm{Exp}=$ exopodite; $\mathrm{Fu}=$ furcal rami; $\mathrm{Ga}=$ genital field; $\mathrm{Gsg}=$ genital somite; $\mathrm{Md}=$ mandible; $\mathrm{Mx}=$ maxilla; $\mathrm{Mxl}=$ maxillule; $\mathrm{Mxp}=$ maxilliped; $\mathrm{Op}=$ anal operculum; P1-P5= thoracic appendages; $\mathrm{R}=$ rostrum.

The nomenclature and descriptive terminology follow Dussart \& Defaye (1995) and Huys \& Boxshall (1991).

For both species, the material of the typical series is temporarily deposited at the "Dipartimento di Scienze Ambientali, Università della Tuscia", Viterbo (senior author's collection) except for the holotype and one female paratype, deposited in the collection of the "Museo Civico di Storia Naturale A. Doria", Genoa (Italy).

Fam. PARASTENOCARIDIDAE Chappuis, 1933

Gen. Parastenocaris Kessler, 1913

Parastenocaris aesculapii $\mathrm{n}$. sp.

\section{Type material}

Holotype: 1 male, V. Cottarelli leg., 5-04-1992, hyporheic water of a small stream near the Asklepeion, in Kos, Dodecanese Islands, dissected and mounted on a slide labelled: Kos - Parastenocaris aesculapii ht. Paratypes: 1 male and 5 females from the same station, V. Cottarelli leg., 23-031989 ; 24-02-1990, 5-04-1992, also mounted on slides numbered from 1 to 6, labelled: Kos - Parastenocaris aesculapii pt.

\section{Description of the holotype}

Body cylindrical and elongate, unpigmented, eyeless; length, from the rostrum to the distal apex of the furcal rami: $0.387 \mathrm{~mm}$.

Anal operculum (Fig. 2): rounded, with a row of spinules near the distal margin.

Furcal rami (Fig. 2): shorter than the last abdominal somite; length/ width ratio: 3.5. Armature consisting of a group of three setae of different length at about $2 / 3$ of the lateral outer margin, a composite long dorsal seta, a long and strong main apical seta flanked by a short inner and a somewhat longer outer setae.

Rostrum and antennule (Fig. 3): rostrum as in figure. Antennule: first segment bare, second segment with five distal setae, one is plumose; third segment with four setae. Fourth segment enlarged, has a seta and a tipped 
apophysis on the proximal margin, a distal tubercle with two setae and an aesthetasc that reaches in length the end of the last segment. Fifth segment partially merged with the previous one, without armature, as the sixth segment, which is lengthened in a strong curved tip. Seventh segment with eight setae and an aesthetasc.

Antenna (Fig. 4): one-segmented exopodite with a slender apical seta; allobasipodite with a row of cuticular spinules at about half of the inner lateral margin. Endopodite bearing distally three geniculated setae, three oneside barbed setae. Remaining ornamentation as in figure.

Mandible (Fig. 7): one-segmented palp, with two distal setae.

Maxillule (Fig. 8): arthrite of the praecoxopodite with three distal curved spines and some spinules; a curved seta is inserted at about half length of the arthrite. Coxopodite with a distal seta, basipodite with two apical setae.

Maxilla (Fig. 9): syncoxopodite with two endites, one bears a normal and a leaf-like setae. The other one with a barbed seta. Basipodite prolonged into an apical curved and spinulose tip with a lateral normal seta. Endopodite reduced to a small tubercle with two setae.

Maxilliped (Fig. 10): slim and elongate; basipodite unarmed, first segment with some small distal spinules; second segment unarmed, with a long, curved and pennate apical spine.

P1 (Fig. 11): exopodite three-segmented, almost as long as the endopodite. Third segment with two geniculate apical setae, an apical and a subapical spines. Endopodite two-segmented; second segment with a long and geniculate and a barbed setae on the apex.

P2 (Fig. 12): exopodite three-segmented, armature shown in figure. Endopodite shorter than $1 / 3$ of the first segment of the corresponding exopodite, represented by a little cylindrical segment, with some apical spinules and one seta.

P3 (Fig. 16): squat, basipodite with a row of spinules and a long seta; a row of very small spinules near the lateral inner margin. Endopodite is missing. First segment of the exopodite ending in a strong and long apophysis with a group of four cuticular spinules inserted on the outer margin. Second segment represented by a leaf-like appendix, almost as long as the apophysis, with undulating margins.

P4 (Fig. 15): Exopodite three-segmented, chaetotaxy as shown in figure. Endopodite as long as half of the first segment of the corresponding exopodite, outer margin with a row of spinules decreasing in length proximally to distally. On the basipodite, near the insertion of the endopodite, a short barbed seta. 


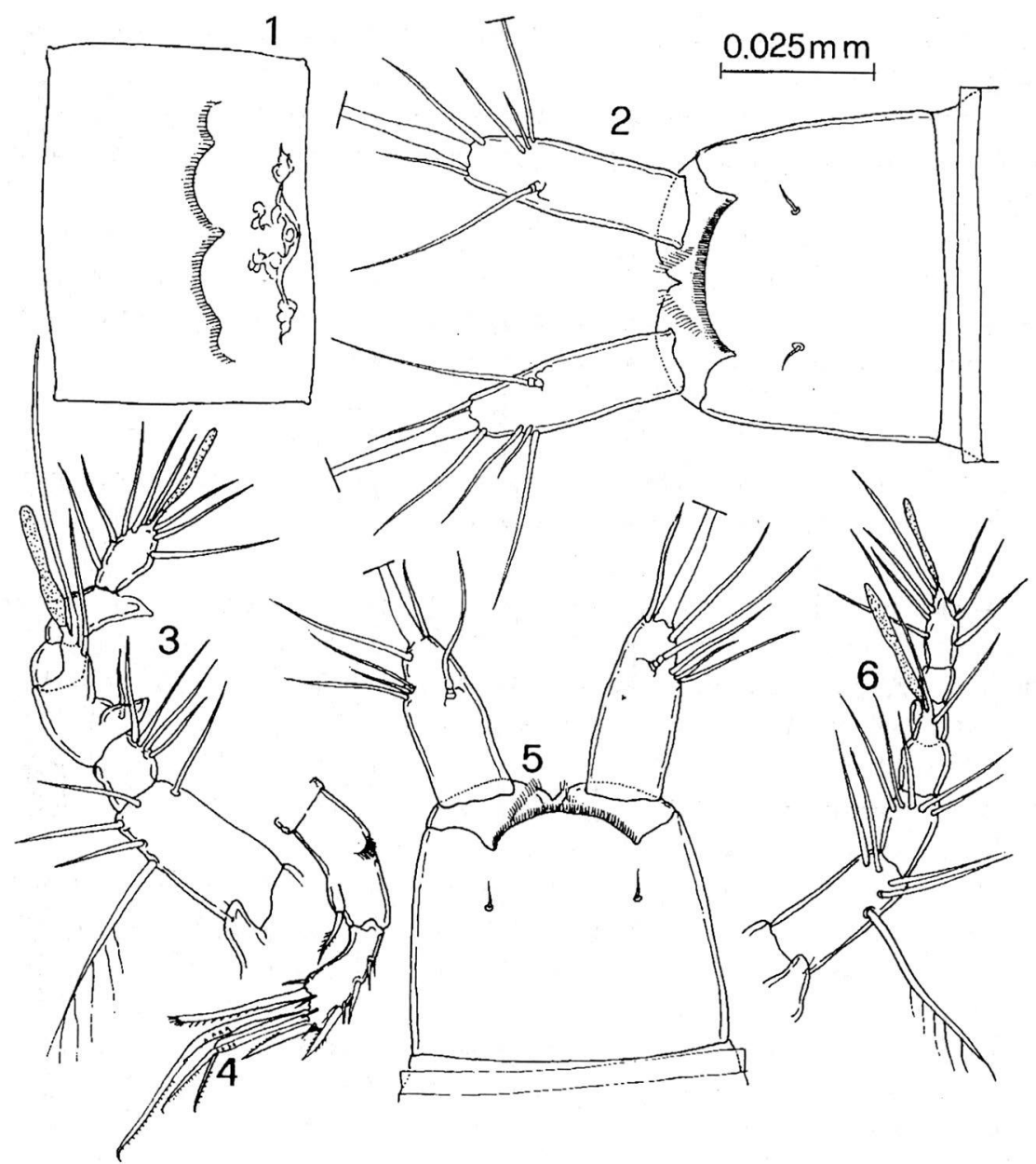

Figs. 1-6 - Parastenocaris aesculapii n. sp. 2,3,4: holotype male. 1,5,6: paratype female. 1, Gsg and $\mathrm{Ga} ; 2$, Op and Fu; 3, R and A1; 4, A2; 5, Fu; 6, A1.

P5 (Fig. 13): represented by a sharpened plate of approximately triangular shape, prolonged in a strong tip. About half way along the distal margin are one long and two short setae.

\section{Description of the paratype (female)}

Length: $0.396 \mathrm{~mm}$. Rostrum, antenna, oral appendages, maxilliped, P1, $\mathrm{P} 2$ and P4 exopodite, anal operculum, as in the male. Genital somite provi- 
ded ventrally with an undulated row of spinules, below the genital field (Fig. 1).

Furcal rami (Fig. 5): with the same armature as in the male, but shorter. Length/width ratio: 2.6 .

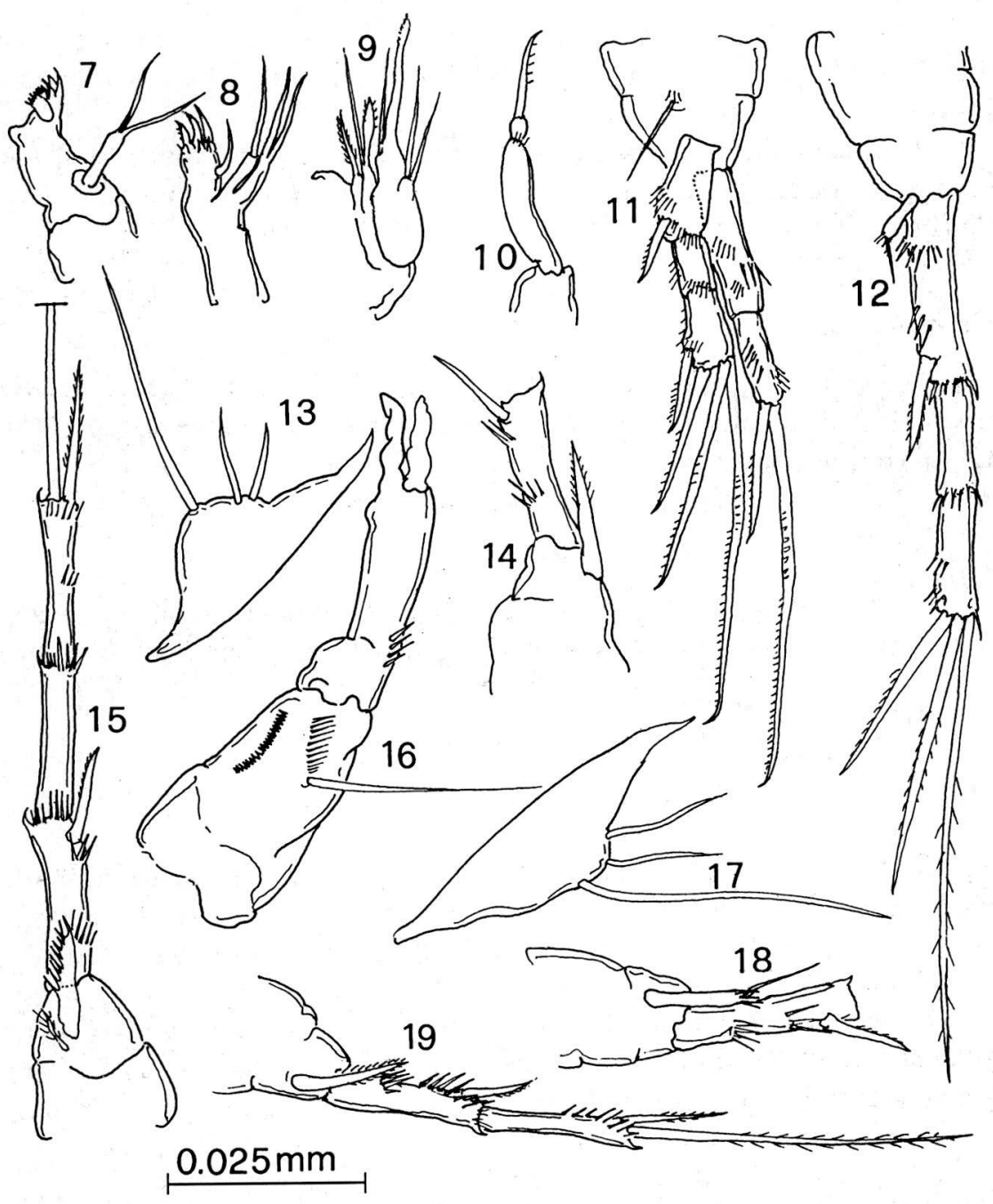

Figs. 7-19 - Parastenocaris aesculapii n. sp. 7,8,9,10,11,12,13,15,16: holotype male. 14,17,18,19: paratype female. 7, Md; 8, Mxl; 9, Mx; 10, Mxp; 11, P1; 12, P2; 13, P5; 14, Enp P4; 15, P4; 16, P3; 17, P5; 18, Enp P2; 19, P3. 
Antennule (Fig. 6): seven-segmented, second segment with a plumose composite seta and four distal setae; third segment with five distal setae. Fourth segment with a distal tubercle bearing two long setae and an aesthetasc. Seventh segment with an aesthetasc on the apex and seven marginal setae.

P2 endopodite (Fig. 18): similar to the male's one but longer, with the same ornamentation.

P3 (Fig. 19): endopodite represented by a sharp barbed spine, longer than $2 / 3$ of the corresponding two-segmented exopodite, which is armed as in figure.

P4 endopodite (Fig. 14): a little shorter than the first segment of the corresponding exopodite, with sharp apex and some apical spinules. P5 (Fig. 17): similar to the male's one, but with longer setae.

\section{Derivatio nominis}

The species name has been chosen since the species has been collected near the Askleipeion, the famous temple dedicated to Aesculapius, the Greek God of Medicine.

\section{Variability}

The features described above appear to be constant in all the specimens of the typical series, except for some small variations in the total length values.

\section{Relationships}

Parastenocaris aesculapii n. sp. is well characterised by the morphology and ornamentation of P3 and P4 endopodite in males and of furcal ra$\mathrm{mi}$ in both sexes, but its arrangement of features makes difficult to identify the affinities. The simple structure of P4 endopodite in males, accompanied by a single seta near its insertion, is not so frequently occurring at least between the European Parastenocaris. The same features are shared, for example, by $P$. budapestiensis Török, 1935, from Budapest and by $P$. nolli Kiefer, 1938 from Germany. The male's P3 of $P$. aesculapii also resembles to the same appendix of $P$. nolli and $P$. italica Chappuis, 1953, a species distributed not only in Italy, but also in Macedonian and Turkey. Moreover, another species, still in study, from Turkey shows some morphological affinities with $P$. aesculapii. 
Parastenocaris aphroditis $\mathrm{n}$. sp.

\section{Type material}

Holotype: 1 male, M.C. Bruno and V. Cottarelli legg., 3-04-1996, hyporheic water of a small stream mouth in Kastraki beach, near Paleopolis, in Kythira Island, dissected and mounted on a slide labelled: Kythira - $\mathrm{Pa}$ rastenocaris aphroditis ht. Paratypes: 21 males and 32 females from the same station, also mounted on slides numbered from 1 to 53 , labelled: Kythira - Parastenocaris aphroditis pt.

\section{Description of the holotype}

Body cylindrical and elongate, unpigmented, eyeless; length, from the rostrum to the distal apex of the furcal rami: $0.354 \mathrm{~mm}$.

Anal operculum (Fig. 25): with smooth, rounded margin.

Furcal rami (Fig. 20): subcylindrical, shorter than the last abdominal segment; length/width ratio: 2.2. Armature consisting of a subapical composite dorsal seta, a long main apical seta flanked by two shorter ones of different length, two short subapical outer setae.

Rostrum and antennule (Fig. 21): rostrum as in figure. Antennule: first segment bare, second segment with four normal and a plumose seta; third segment with five apical setae. Fourth segment enlarged, brings distally one seta near the origin of a tubercle bearing a seta and an aesthetasc that reaches in length the end of the last segment. Fifth segment partially merged with the previous one, with no armature, as the sixth segment which is lengthened in a strong curved tip. Seventh segment with seven setae and an aesthetasc.

Antenna (Fig. 30): one-segmented exopodite with a slender apical seta; allobasipodite unarmed. Endopodite bearing distally two geniculate and three barbed setae. Remaining ornamentation as in figure.

Mandible (Fig. 26): one-segmented palp, with two distal setae.

Maxillule (Fig. 27): arthrite of the praecoxopodite with four distal curved spines; a long and curved seta is inserted at about half length of the arthrite. Coxopodite with a long distal seta, basipodite with two apical setae.

Maxilla (Fig. 28): syncoxopodite with two endites, one bears a normal and a geniculate setae, the other endite bears one normal seta. Basipodite prolonged into an apical curved and distally spinulose tip, with a lateral seta. Endopodite represented by a small tubercle with two setae. 


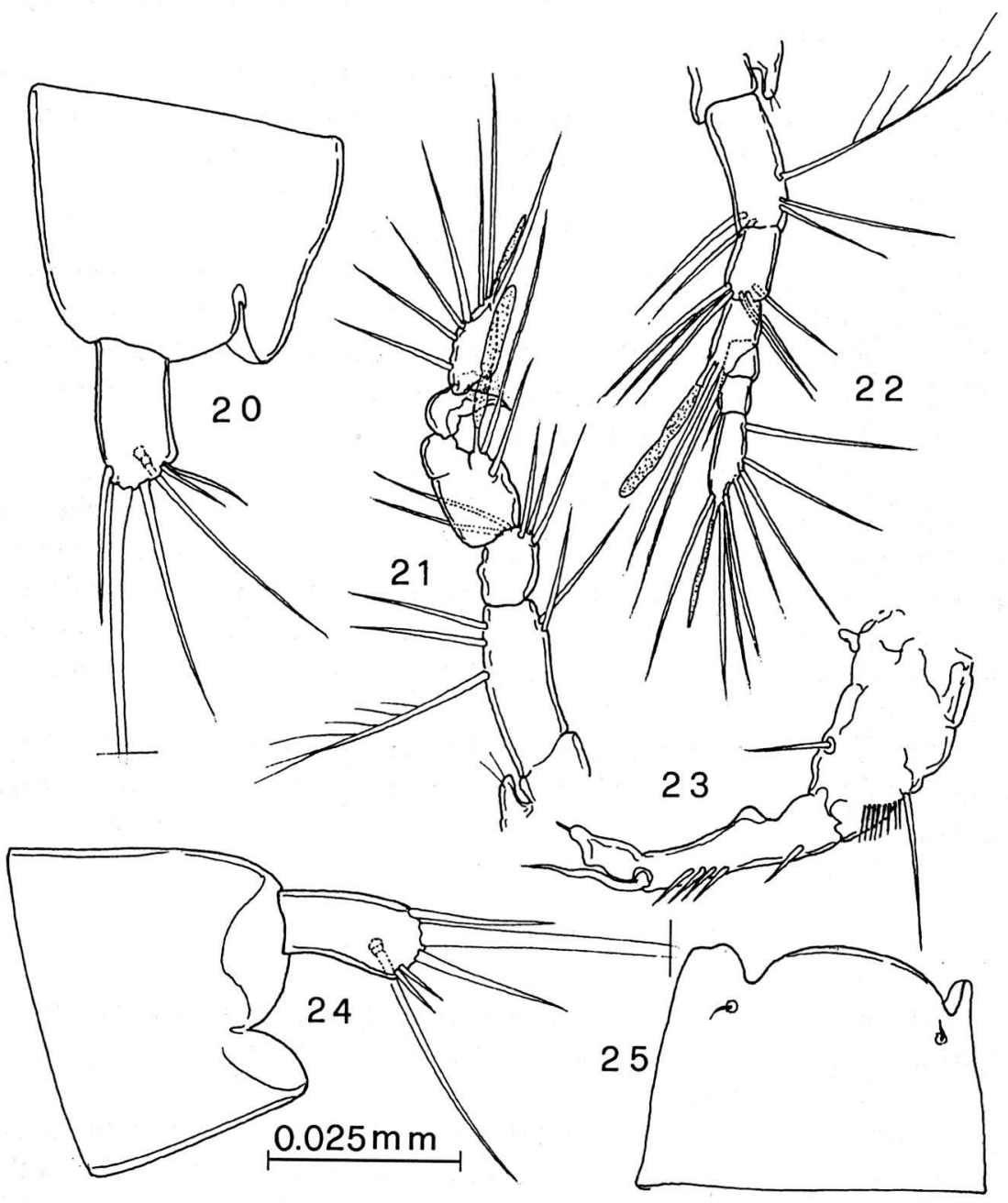

Figs. 20-25 - Parastenocaris aphroditis n. sp. 20,21,23,25: holotype male. 22,24: paratype female. 20, Fu; 21, R and A1; 22, A1; 23, P3; 24, Fu; 25, Op.

Maxilliped (Fig. 29): slim and elongate; basipodite and first segment unarmed, second segment with an apical long, curved and one-side barbed spine.

P1 (Fig. 31): basipodite with a hook near the endopodite insertion. Exopodite three-segmented, almost as long as the endopodite. Third segment with two geniculate, an apical and a subapical spines. Endopodite 
two-segmented, second segment with a long and geniculate and a barbed setae on the apex.

P2 (Fig. 32): exopodite three-segmented, armature shown in figure. Endopodite almost as long as half of the first segment of the corresponding exopodite, represented by a cylindrical segment with some apical spinules and one seta.

P3 (Fig. 23): quite squat, basipodite with a row of spinules and a long seta; endopodite represented by a seta. First segment of the exopodite with a proximal spine near the lateral outer margin and a group of four spines on the same margin, ending in a leaf-like apophysis with undulating margin and a spinule on the apex. Second segment longer than the end of the apophysis, represented by a thin, elongate appendix.

P4 (Fig. 34): exopodite three-segmented, chaetotaxy as shown in figure. Endopodite as long as the second segment of the corresponding exopodite, with the first third smooth and a roundish lateral apophysis. The remaining terminal part of the endopodite is leaf-like, sharpening to the top, with small lateral tubercles and spinules. Near the insertion of the endopodite are inserted a thick spine with curved tip, almost as long as $1 / 3$ of the endopodite itself and a shorter and thinner spine.

P5 (Fig. 33): represented by a plate of approximately rectangular shape, prolonged in a distal inner tip. Four setae of different length along the distal margin.

\section{Description of the paratype (female)}

Length: $0.363 \mathrm{~mm}$. Furcal rami, rostrum, antenna, oral appendages, maxilliped, P1, exopodite P2 and P4, anal operculum, as in the male.

Furcal rami (Fig. 24).

Antennule (Fig. 22): seven-segmented, second segment with three normal and a plumose setae; third segment with five distal setae. Fourth segment with a distal tubercle bearing two setae and a long aesthetasc. Sixth segment with a distal short seta; seventh segment with an aesthetasc on the apex and eighth terminal setae.

P2 endopodite (Fig. 37): similar to the male's one, with the same ornamentation.

P3 (Fig. 35): endopodite transformed in a strong spine with curved tip, a little longer than the first segment of the corresponding two-segmented exopodite, which is armed as in figure.

P4 endopodite (Fig. 38): a little longer than the first segment of the corresponding exopodite, ending in a tip, with some small distal spinules. 
P5 (Fig. 36): with the same ornamentation as in the male, but slimmer and longer.

\section{Derivatio nominis}

The species name has been chosen since Kythira is the island were the cult of Aphrodite, in the ancient time, has started.

\section{Variability}

The features described above appear to be constant in all the specimens of the typical series, except for some small variations of the total length values in the paratypes.

\section{Relationships}

Parastenocaris aphroditis $\mathrm{n}$. sp. belongs to the minuta group Lang 1948, and shows the closest affinities with some of the species of this group: $P$. andalusica Enckell, 1965, P. hera Cottarelli, 1969, P. stellae Cottarelli, Saporito \& Puccetti, 1981, P. rivi Cottarelli \& Bruno, 1994, P. oligoalina Cottarelli, Bruno \& Venanzetti, 1995, P. etrusca Cottarelli, Bruno \& Venanzetti, 1995. All of these species, as well as P. aphroditis n. sp., have been collected in the estuarine hyporheos of streams and rivers and in the Mediterranean area; all of them share a similar ecology and a peculiar habitus, expressed mainly in male's P3, in furcal rami, in endopodite P2 and P5 in both sexes. However, the new species is easily distinguishable by the ornamentation of the first segment of male's P3, by the presence of both the long and hooked and the short and straight spines near the insertion of endopodite P4 in males, by the remarkable length of this endopodite, by the shape and size of endopodite P4 in females. In particular, the morphology of endopodite $\mathrm{P} 4$ in males of $P$. aphroditis n. sp., $P$. andalusica and $P$. etrusca is similar (Cottarelli et al., 1995b; Rouch, 1990). As regards male's P3, only in $P$. stellae the spines on the first segment of the exopodite are arranged in two groups (one group is made of two spines at about $1 / 3$ of the length, the other one of a distal row of five spines); in all the Parastenocaris mentioned before there is only a distal raw composed by a variable number of spines.

The morphology and ornamentation of P5 is quite constant in all the Parastenocaris so far discussed: in P. hera, P. stellae, P. oligoalina, $P$. etrusca it is an approximately rectangular plate, prolonged distally in an inner tip with four marginal setae of different length, in $P$. rivi the inner tip is 


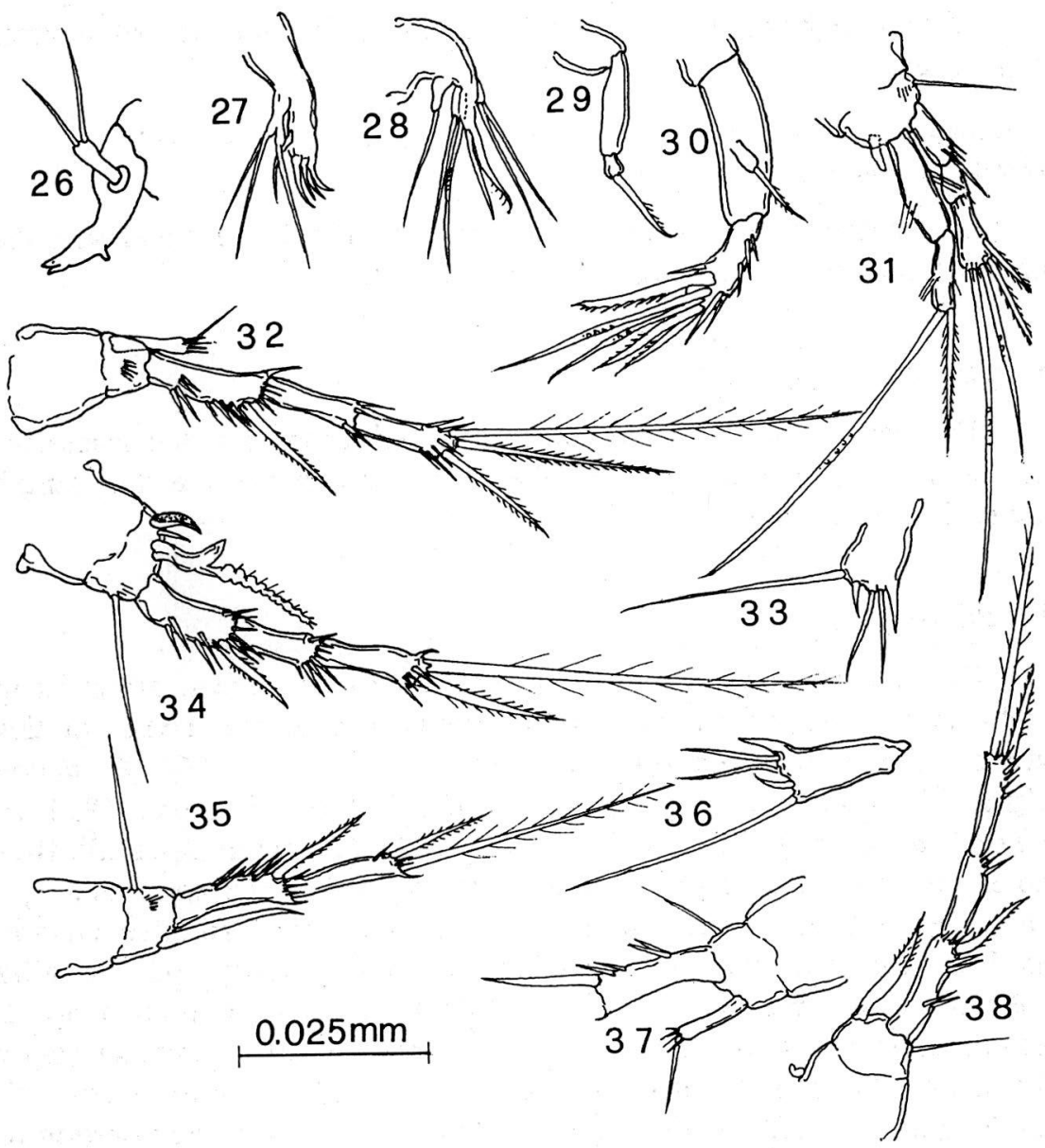

Figs. 26-38 - Parastenocaris aphroditis n. sp. 26,27,28,29,30,31,32,33,34: holotype male. 35,36,37,38: paratype female. 26, Md; 27, Mxl; 28, Mx; 29, Mxp; 30, A2; 31, P1; 32, P2; 33, P5; 34, P4; 35, P3; 36, P5; 37, Enp P2; 38, P4.

substituted by a spine. $P$. andalusica differs because P5 has a triangular shape and bears only three setae.

In previous works Cottarelli \& Bruno (1994), Cottarelli et al. (1995b) had already noticed that it can be useful, in order to distinguish species with a very close morphology, as in this case, to use features such as maxillules and maxillae, that are not usually considered in the taxonomy of this genus. Accordingly, we summarise in the following list the data regarding all the Parastenocaris of Mediterranean rivermouths. 


\begin{tabular}{|c|c|c|c|}
\hline & Maxillules & Maxillae & \\
\hline P. andalusica & Not described & Not described & \\
\hline P. aphroditis & $\begin{array}{l}\text { Arthrite: } 4 \text { distal spines } \\
\quad 1 \text { lateral seta } \\
\text { Coxa: } 1 \text { seta } \\
\text { Basipodite: } 2 \text { setae }\end{array}$ & $\begin{array}{l}\text { Endopodite: } \\
\text { Endite 1: } \\
\text { Endite 2: }\end{array}$ & $\begin{array}{l}2 \text { setae } \\
2 \text { setae } \\
1 \text { seta }\end{array}$ \\
\hline P. etrusca & $\begin{array}{ll}\text { Arthrite: } & 3 \text { distal spines } \\
& 1 \text { lateral seta } \\
\text { Coxa: } \quad 1 \text { seta } \\
\text { Basipodite: } 2 \text { setae }\end{array}$ & $\begin{array}{l}\text { Endopodite: } \\
\text { Endite 1: } \\
\text { Endite 2: }\end{array}$ & $\begin{array}{l}2 \text { setae } \\
2 \text { setae } \\
1 \text { seta }\end{array}$ \\
\hline P. hera & $\begin{array}{ll}\text { Arthrite: } & 2 \text { distal spines } \\
& 1 \text { lateral seta } \\
\text { Coxa: } \quad 1 \text { seta } \\
\text { Basipodite: } 2 \text { setae }\end{array}$ & $\begin{array}{l}\text { Endopodite: } \\
\text { Endite 1: } \\
\text { Endite 2: }\end{array}$ & $\begin{array}{l}1 \text { seta } \\
2 \text { setae } \\
\text { missing }\end{array}$ \\
\hline P. oligoalina & $\begin{array}{ll}\text { Arthrite: } & 3 \text { distal spines } \\
& 1 \text { lateral seta } \\
\text { Coxa: } \quad 1 \text { seta } \\
\text { Basipodite: } 3 \text { setae }\end{array}$ & $\begin{array}{l}\text { Endopodite: } \\
\text { Endite 1: } \\
\text { Endite 2: }\end{array}$ & $\begin{array}{l}2 \text { setae } \\
2 \text { setae } \\
\text { missing }\end{array}$ \\
\hline P. rivi & $\begin{array}{l}\text { Arthrite: } 3 \text { distal spines } \\
\text { Coxa: } 1 \text { seta } \\
\text { Basipodite: } 2 \text { setae }\end{array}$ & $\begin{array}{l}\text { Endopodite: } \\
\text { Endite 1: } \\
\text { Endite 2: }\end{array}$ & $\begin{array}{l}2 \text { setae } \\
2 \text { setae } \\
1 \text { seta }\end{array}$ \\
\hline P. stellae & Not described & $\begin{array}{l}\text { Endopodite: } \\
\text { Endite 1: } \\
\text { Endite 2: }\end{array}$ & $\begin{array}{l}1 \text { seta } \\
1 \text { seta } \\
2 \text { setae }\end{array}$ \\
\hline
\end{tabular}

\section{DISCUSSION}

The discovery of these Greek Parastenocaris fills a gap in the distribution of Parastenocaris in the Mediterranean area. In particular the already mentioned relationships between $P$. aesculapii n. sp. and a Turkish congeneric species can be explained by the occurrence of past links between Kos Island and Turkey. Kos is nowadays only five kilometres distant from Bodrum, on the Turkish Coast and the two lands were connected during Tortonian-Messinian, (Sondaar et al., 1986; Dermitzakis, 1990) and even for a long time in Pleistocene, (Audisio \& De Biase, 1990).

The discovery of $P$. aphroditis $\mathrm{n}$. $\mathrm{sp}$. allows to better trace the distribution of the species group minuta, confirming that the group is widely represented in Southern Europe and in the Mediterranean Islands. It has been 
collected not only on large islands such as Sicily (Pesce et al., 1988) and Sardinia (Cottarelli et al., 1995a), but also on little islands such as Kos, Kythira, San Pietro (Sardinia) (Cottarelli \& Bruno, 1994); in Montecristo (Tuscany Archipelago) have been collected (Cottarelli \& Torrisi, 1976) only female specimens of a species probably belonging to the same group.

As regards continental Greece, there are not data concerning the presence of Parastenocaris: Pesce \& Maggi (1983), report of a Parastenocaris sp. from Northern Greece that has never been mentioned in further papers. Anyway, it will be probably possible to demonstrate a wide distribution for this genus in continental Greece too, if some peculiar habitats, such as hyporheos and lacustrine psammon, will be sufficiently investigated.

The researches on the interstitial meiofauna adapted to the estuarine ecotone that we have been carrying out for several years, allow us to identify the group of six Parastenocaris in the minuta species group, $(P$. andalusica, $P$. etrusca, $P$. hera, $P$. oligoalina, $P$. rivi, $P$. stellae) that share peculiar morphological affinities. These species are the only ones tipically living in Perimediterranean Europe in estuarine habitats, where the ecological factors have a wide variability, to which the Parastenocaris discussed here seem to be the only adapted species. In fact $P$. hera, distributed in Central and Southern Italy, has been found only in sandbanks from the mouth of Sele River to 450 meters upriver, where this species is replaced by other Parastenocaris. P. hera shows the same spatial distribution in Volturno and Garigliano Rivers; the same pattern has been detected for $P$. etrusca and $P$. stellae, collected from Fiora River (Central Italy) and Cedrino River (Sardinia) respectively, that are replaced upriver by other species of Parastenocaris. When the streams are short and small, as those where P. oligoalina (from a small stream in Sardinia), $P$. rivi (from a small stream in $\mathrm{S}$. Pietro Island, near the Sardinian Western Coast) and P. aphroditis (from a small stream mouth) live, only these species, typical of estuarine habitats, have been collected. In any case, all the species mentioned here have been often found together with harpacticoids of the genus Psammopsyllus Nicholls, 1945 and Ichnusella Cottarelli, 1971. P. andalusica has been collected in Rio Fuengirola, Malaga, Spain, in "sandbank 300 meters from the river mouth. Freshwater interstitial habitat, hardly affected by sea waters" (Enckell, 1965).

Two hypotheses can be proposed about the origin of these related taxa: according to the first one, some ancestors already adapted to life in subterranean freshwater would have from this habitat "re-colonised" the estuaries. In this case, the observed morphological and ecological similarities could reflect strong evolutionary convergence in a discrete number of species, di- 
stributed on a wide area. According to the second hypothesis, that seems to us more convincing, it can be assumed a common origin of these Parastenocaris from an ancestor adapted to life in the river mouths around the Mediterranean Sea, which would have colonized continental hyporheic habitats afterwards. The ancestor should have already had those morphological characters, probably in a plaesiomorphic state, that are still shared by this group of Parastenocaris.

\section{ACKNOWLEDGEMENTS}

These researches have been supported by grants from M.U.R.S.T (40\%) and C.N.R; some samples have been collected (1989) during researches carried out with the Oceanographic Ship Bannock, belonging to the Italian "Consiglio Nazionale delle Ricerche".

\section{REFERENCES}

AUDISIO, P. e A. DE BIASE. 1990. Materiali per una biogeografia delle Hydraena e Haenidra della Grecia e delle isole egee. I Contributo (Coleoptera, Hydraenidae). Fragm. Entomol. 22 (2): 381-398.

BRUNO, M.C. and. V. COTTARELLI. New records of Harpacticoids (Crustacea, Copepoda) from subterranean fresh and brackish waters of Greece. Biol. Gallo-Hellenica, in press.

COTTARELLI, V. 1969. Nuove Parastenocaris (Copepoda, Harpacticoida), dell'Italia centro-meridionale. Riv. Idrobiol. 8 (3): 1-8.

COTTARELLI, V. e M.R. TORRISI. 1976. Ciclopoidi e Arpacticoidi (Crustacea, Copepoda) di acque sotterraneee dell'Isola di Montecristo (Arcipelago Toscano). Lav. Soc. It. Biogeogr. n. s. 5: 357-370.

COTTARELLI, V., P.E. SAPORITO e A. PUCCETI. 1981. Parastenocaris stellae n. sp. della falda iporreica del fiume Cedrino (Sardegna) (Crustacea, Copepoda, Harpacticoida). Fragm. Entomol. 16 (1): 1-7.

COTTARELLI, V. e M.C. BRUNO. 1994. Parastenocaris rivi n. sp. di acque iporreiche dell'isola di S. Pietro (Sardegna). Ann. Mus. Civ. St. nat. G. Doria, Genova. 90: 509-519.

COTTARELLI, V., M.C. BRUNO e C. FORNIZ. 1995a. Copepodi Arpacticoidi e Sincaridi (Crustacea) di acque sotterranee delle isole circumsarde. Lav. Soc. Ital. Biogeogr., in press.

COTTARELLI, V., M.C. BRUNO and F. VENANZETTI. 1995b. Two new species of Parastenocaris from the interstitial waters of rivermouths in Latium and Sardinia (Crustacea, Copepoda, Harpacticoida). Fragm. Entomol. 26 (2): 229-247.

DERMITZAKIS, M.D. 1990. Paleogeography, Geodynamic processes and Event Stratigraphy during the Late Cenozoic of the Aegean Area, pp. 263-288. In: Biogeograhical aspects of Insularity. Atti Convegno Lincei. 85.

DUSSART, R. et D. DEFAYE. 1990. Rèpertoire mondial des Crustacés Copépodes des eaux intérieurs. III. Harpacticoïdes. E. J. Brill (ed.), Leiden, The Netherlands.

DUSSART, R. and D. DEFAYE. 1995. Introduction to Copepoda. SPB Academic Publishing, Amsterdam, The Netherlands.

ENCKELL, P.H. 1965. New Harpacticoids of Spain. Acta Univ. Lund. 2 (19): 1-9.

FORNIZ, C., F. VENANZETTI and V. COTTARELLI. 1990. First record of phreatic harpacticoids from some Aegean islands (Abstract). 5th International Congress on the Zoogeography and Ecology of Greece and adjacent Regions. Iraklion, Crete: 75.

HUYS, R. and G. BOXSHALL. 1991. Copepod evolution. The Ray Soc., London.

LANG, K. 1948. Monographie der Harpacticiden. Nord. Bokhand., Stockholm. 
PESCE, G.L. 1981. Some remarks on the stygofauna of Greece. Biol. Gallo-hellenica. 10: 103-112.

PESCE, G.L. 1985. Stygobiological researches in subterranean waters of Lesbos (Greece) and description of Stygonitocrella petkovskii n.sp. (Crustacea, Copepoda: Ameiridae). Fragm. balcanica. 12 (273): 125-139.

PESCE, G.L. e D. MAGGI. 1983. Ricerche faunistiche in acque sotterranee della Grecia meridionale ed insulare e stato attuale delle conoscenze sulla stigofauna di Grecia. Natura, Milano. 74 (1-2): 15-73.

PESCE, G.L., D.P. GALASSI and V. COTTARELLI. 1988. First representative of the family Parastenocarididae from Sicily (Italy), and description of two new species of Parastenocaris Kessler (Crustacea, Copepoda: Harpacticoida). Bull. Zool. Mus. Amsterdam. 11: 137-142.

ROUCH, R. 1990. Deux nouvelles Parastenocaris (Copépodes, Harpacticoides) des Pyrénées. Annls Limnol. 26 (1): 19-28.

SOONDAR, P.Y., J. DE VOS and M.D. DERMITZAKIS. 1986. Late Cenozoic Faunal Evolution and Paleogeography of the South Aegean Islands. Arc. Modern Geology. 10: 249259. 